\title{
Red Blood Cell Processing
}

National Cancer Institute

\section{Source}

National Cancer Institute. Red Blood Cell Processing. NCI Thesaurus. Code C112928.

Any procedure used to process or manipulate units of red blood cells. 